\title{
Quality and mineral composition of eggs from hens supplemented with copper-lysine chelate
}

\author{
Antoni Brodacki ${ }^{1}$, Justyna Batkowska ${ }^{1}$, Anna Stępniowska ${ }^{2}$, Eliza Blicharska ${ }^{3}$, and Kamil Drabik ${ }^{1}$ \\ ${ }^{1}$ Institute of Biological Basis of Animal Production, The University of Life Sciences in Lublin, \\ 13 Akademicka St., 20-950 Lublin, Poland \\ ${ }^{2}$ Department of Biochemistry and Toxicology, The University of Life Sciences in Lublin, \\ 13 Akademicka St., 20-950 Lublin, Poland \\ ${ }^{3}$ Department of Analytical Chemistry, Faculty of Pharmacy with Medical Analytics Division, \\ Medical University of Lublin, 4a Chodzki St., 20-093 Lublin, Poland
}

Correspondence: Justyna Batkowska (justyna.batkowska@up.lublin.pl)

Received: 14 November 2017 - Revised: 13 January 2018 - Accepted: 19 January 2018 - Published: 2 March 2018

\begin{abstract}
The aim of study was to evaluate the quality of hen eggs influenced by supplementation of copper with lysine chelate (CHL). The material consisted of eggs from two groups of Hy-Line Brown laying hens aged 300 days. Group I, negative control (NC), did not receive any additives. The hens from group II were treated with CHL at a dose of $30 \mathrm{mg} \mathrm{Cu} \mathrm{L}^{-1}$ with drinking water. After 4 weeks of supplementation, 60 eggs from each group were randomly collected for quality analysis. The characteristics of the whole egg and its individual elements (shell, yolk, and albumen) were evaluated. The supplementation of CHL increased the egg weight, as well as the weight and height of albumen. There were no changes in the shell strength parameters, and its darker color may increase potential consumer acceptance, but requires confirmation by sensory analysis of the eggs. The copper addition was relatively small, but even this dose caused some changes in egg quality. Little changes in the mineral composition of individual elements of the eggs have been reported. It is therefore very important to continue research to find the smallest effective dose of this micronutrient, to study the duration of time it should be given in order to obtain the best quality of eggs, and to minimize the mineral disorders in organisms.
\end{abstract}

\section{Introduction}

A lot of factors may modify table egg quality: the genotype (Batkowska and Brodacki, 2017), age of the hens (Zita et al., 2009; Sarica et al., 2012), environmental conditions, including rearing systems (Đukić-Stojčić et al., 2009; Batkowska et al., 2014), as well as feed additives (Safaa et al., 2008), which include micro-and macroelement supplementation. The microelement most commonly used in poultry production is copper. This element is a component of many enzymes and also their activator. It is a cofactor of superoxide dismutase, an enzyme-inhibiting free radical reactions (Wieleba and Pasternak, 2001). In terms of table egg production, copper contributes to an increase in shell strength (Pekel et al., 2011) and the reduction of cholesterol content in yolk (Lim et al., 2006). Copper deficiency may limit egg production and increase the number of eggs with irregular size and shape, resulting in wrinkled, thick and textured shells or even eggs without shells (Baumgartner et al., 1978).

Micro-and macroelements are added mainly in inorganic form. However, studies show that both the recommended doses and estimated requirements of the hens are too high, and that the availability of inorganic compounds is insufficient (Esenbuğa et al., 2008; Zhao et al., 2010). This is due to the limited absorption capacity of the gastrointestinal tract caused by the attachment of these micronutrients by various compounds (phytates, fiber fractions, and tannins). Such complexes are persistent, difficult to absorb, and are excreted, causing further environmental contamination (Atia et al., 2000). Consequently, mineral supplementation with better absorption is sought after and for this purpose, chelates are suitable. In these compounds, one part is most often an amino acid and the other is a metal ion. Metals of 
metal ions with organic substances such as amino acids, peptides or polysaccharide complexes provide greater bioavailability, stability and solubility. Thanks to these properties of chelates, the microelements are easily transported and absorbed in the hen's intestines. Additionally, they are more stable and biochemically protected against reactions to other ingredients that may limit their absorption (Paik, 2000).

Available research connected to copper supplementation in poultry feeding differs in obtained results. Part of the research showed that copper had a beneficial influence. The rest of the research revealed that copper does not change the physiological parameters or the quality of poultry products (Lim and Paik, 2003; Olgun et al., 2012; Stanćev et al., 2013; Yenice et al., 2015). The purpose of the study was to evaluate the quality of hen eggs affected by the supplementation of copper chelate with lysine (CHL) through combining issues such as possible copper deficiencies, the form of its administration, and lack of unequivocal data connected to the influence of this mineral.

\section{Material and methods}

The study was carried out on 400 Hy-Line Brown hens. The stock was maintained in the litter system and achieved sexual maturity at the age of 21 weeks. In the diet, standard balanced mixtures for laying hens were used (Table 1). The hens were randomly divided into two groups. Group I, consisting of 200 hens, was a negative control (NC) group fed without any additives. Group II, also consisting of 200 hens, was the experimental group supplemented with $30 \mathrm{mg} \mathrm{Cu} \mathrm{L}^{-1} \mathrm{CHL}$ in drinking water for four weeks. During the whole experiment, principles of ethics and the welfare of the hens were maintained (Council Directive, 1999/74). After two weeks, 60 eggs from each group were randomly collected.

The following traits were evaluated: egg weight, features describing shell (color, strength, weight, thickness, and density), albumen (weight and Haugh units), and yolk (color and weight) using electronic set EQM (Egg Quality Measurements by $\mathrm{TSS}^{\circledR}$ ) and Instron Mini 55 devices. Proportions of individual elements of eggs were calculated as well.

Samples of the egg content, yolk, and albumen, were collected to determine the mineral composition. The samples were subjected to mineralization, followed by the determination of $\mathrm{Cu}, \mathrm{Zn}, \mathrm{Fe}, \mathrm{Mg}$, and $\mathrm{Ca}$ through atomic absorption spectrometry (AAS) and the phosphorus (P) content was measured using the colorimetric method (Fiske and Subarow, 1925).

The data were analyzed with the use of statistical package SPSS ver. 21.0 (IBM, 2011). The normality of the data was verified using the Kolmogorov-Smirnov test and the difference between groups was determined through the $t$-test.
Table 1. Nutritional value of feed in both groups of laying hens during the experiment.

\begin{tabular}{lll}
\hline Ingredient & unit & amount \\
\hline Metabolic energy & $\mathrm{MJ} \mathrm{kg}^{-1}$ & 11.30 \\
\hline Total protein & $\%$ & 17.00 \\
Crude fat & $\%$ & 4000 \\
Crude fiber & $\%$ & 4000 \\
\hline Calcium & $\%$ & 3.600 \\
Available phosphorus & $\%$ & 0.400 \\
Sodium & $\%$ & 0.150 \\
\hline Lysine & $\%$ & 0.760 \\
Methionine & $\%$ & 0.360 \\
Met. + Cyst. & $\%$ & 0.640 \\
Tryptophan & $\%$ & 0.170 \\
\hline Vitamin A & $\mathrm{IU} \mathrm{kg}^{-1}$ & 9000 \\
Vitamin $\mathrm{D}_{3}$ & $\mathrm{IU} \mathrm{kg}^{-1}$ & 2000 \\
Vitamin E & $\mathrm{mg} \mathrm{kg}^{-1}$ & 20.00 \\
\hline
\end{tabular}

\section{Results and discussion}

Table 2 shows the characteristics of the whole egg depending on the group. There was a significant increase in egg weight in the group supplemented with copper chelate. Similar relationships between the groups were reported for the weight and height of albumen. This is confirmed by the fact that larger eggs are also characterized by bigger albumen content (Fletcher et al., 1983) and a higher dense fraction of albumen (Nestor and Jaap, 1963). Eggs from the CHL group were characterized by a $5 \%$ smaller yolk weight. Estimated Haugh units showing the albumen quality (Menezes et al., 2012) were slightly higher in eggs from hens supplemented with copper. Through studies of Ankari et al. (1998) conducted on copper's influence on organisms and productivity of hens, the hens were supplemented with copper, $250 \mathrm{ppm} \mathrm{Cu}$, in a form of sulphate, protein compound, and lysine chelate. Compared to the control group, protein intake was lower in groups 2 and 3 , but the group treated with lysine chelate did not show any difference in comparison to the control group. The copper sulphate group was characterized by better egg production in comparison to other groups, but the eggs were smaller.

Table 2 also contains quality indicators of egg shells. In the group of laying hens fed with CHL, hens were laying eggs with a much heavier shell and larger volume, which explained the greater weight of egg. However, the proportion of the shell in the egg mass and the shell strength recorded in this study did not change as a result of the additive used. Mechanical properties of the shell correspond to the concentration of the matrix proteins and its structure (Ahmed et al., 2005). Changes that occur along with the age of the hens result from the slowing down of the mineralization process and limiting calcium and phosphorus assimilation in the feed. 
Table 2. The quality traits of whole egg and its each elements depending on group.

\begin{tabular}{ll|lll}
\hline \multicolumn{2}{c}{ Trait } & NC & CHL & SEM \\
\hline Egg weight $(\mathrm{g})$ & & $59.36^{*}$ & $63.50^{*}$ & 0.582 \\
\hline \multirow{2}{*}{ Yolk } & weight $(\mathrm{g})$ & 17.32 & 18.33 & 0.223 \\
& proportion $(\%)$ & 29.23 & 28.92 & 0.324 \\
\hline \multirow{4}{*}{ Albumen } & weight $(\mathrm{g})$ & $34.54^{*}$ & $37.32^{*}$ & 0.465 \\
& proportion $(\%)$ & 58.14 & 58.70 & 0.356 \\
& height $(\mathrm{mm})$ & $5.40^{*}$ & $6.05^{*}$ & 0.228 \\
& Haugh units & 69.96 & 73.55 & 2.056 \\
\hline \multirow{4}{*}{ Shell } & weight $(\mathrm{g})$ & $7.49^{*}$ & $7.84^{*}$ & 0.088 \\
& proportion $(\%)$ & 12.63 & 12.38 & 0.121 \\
& strength $(\mathrm{kg})$ & 3.90 & 3.77 & 0.130 \\
& color $(\%)$ & $41.67^{*}$ & $39.12^{*}$ & 0.811 \\
& thickness $(\mu \mathrm{m})$ & 360.5 & 354.6 & 3.717 \\
& surface $\left(\mathrm{cm}^{2}\right)$ & $72.1^{*}$ & $75.4^{*}$ & 0.462 \\
& volume $\left(\mathrm{cm}^{3}\right)$ & 2.60 & 2.67 & 0.034 \\
& density $\left(\mathrm{g} \mathrm{cm}^{-3}\right)$ & 2.89 & 2.94 & 0.029
\end{tabular}

$\mathrm{NC}$ - negative control

$\mathrm{CHL}$ - group supplemented with copper chelate with lysine $30 \mathrm{mg} \mathrm{Cu} \mathrm{L}^{-1}$ in drinking water

* Mean values differ at $p \leq 0.05$

Proper mineralization of the shell is influenced by, among other things, structural proteins, calcium, vitamin D3, vitamin C, chlorine, magnesium, and electrolyte balance in body fluids (Hunton, 2005). Among the micro- and macroelements in the feed in terms of egg shell quality, the most important are calcium and copper. Copper, by increasing bone saturation of calcium, may indirectly affect the strength of shell, which depends significantly on the content of micronutrients in the feed (Yenice et al., 2015). In this study, the applied addition did not significantly change the strength of the shell, but the value of this parameter was slightly lower in the experimental (CHL) group (4.4\%). Lundeen (2001) observed a higher percentage of eggs with a stronger shell and smaller number of crushed eggs after the administration of organic microelements to the feed for 40 and 60-week-old laying hens. Franco and Sakamoto (2001) showed that minerals not only improved the quality of shells but also influenced the chemical quality of eggs, which positively affects their nutritional value and quality during storage.

Olgun et al. (2012) obtained eggs with thicker and heavier shells from hens supplemented with copper in doses from 75 to $300 \mathrm{mg}$ per $\mathrm{kg}$ of feed. The percentage of broken eggs was the smallest in the control group, which may indicate a more fragile shell caused by the mineral supplement. According to Yenice et al. (2015) there are no significant differences in the percentage of the eggs with a broken shell, shape index, proportion and thickness of the shell or height of the dense albumen. However, the shell resistance was reduced in the eggs derived from laying hens supplemented with micronutrients including copper in various forms (organic and inorganic).
Evaluating the effectiveness of various copper organic compounds (Lim and Paik, 2003), copper chelate with methionine, chitosan and yeast were used. It was discovered that Met-Cu chelate not only reduces the number of broken eggs, but also increases the occurrence of gizzard erosion. The most positive influence on egg quality characteristics had yeast preparation, however the shell strength did not differ between the groups. Sechinato et al. (2006) did not state the effect of supplementation with zinc, manganese, copper, iron, or selenium, individually or in combination, in organic or inorganic form, for egg production or quality from hens aged 48-60 weeks. Also Stanćev et al. (2013) indicated that there was no impact of the biocomplex containing copper, manganese, and zinc on the egg weight and the shell quality. It is interesting to note that a darker color of the shells was found, so it seems that this feature does not depend solely on the genotype of the laying hen. Zita et al. (2009) showed a significant positive correlation between the color of the shell and its thickness (0.126), and the negative value of the ratio between the color and the proportion of the shell in the egg mass $(-0.108)$.

Table 3 shows the results of the analysis of the mineral composition of each egg element depending on the additive used. In the yolk, it was found that the lysine chelate administration reduced the iron, magnesium, and calcium content. It was observed that the CHL group also showed higher copper content in the albumen than the control group. Similar relationships between the groups were reported for zinc, magnesium and calcium. However, a statistically significant decrease in iron content was observed. The supplementation did not affect the mineral composition of the egg shell.

The obtained results did not confirm the observations of other authors (Skřivan et al., 2005), where the administration of $25 \mathrm{mg} \mathrm{Cu}$ considerably increased the content of this trace mineral in the yolk and eggshell. The antagonistic relationship between zinc and copper was not confirmed. This may be due to the relatively short time of supplement administration ( 2 weeks), whereas in the cited work, eggs were collected for analysis after 27 days of supplementation. According to Pekel and Aip (2011), regardless of the source, when the content of copper in the egg increased, its content in the hen's feces was four times higher in comparison to the control group. Similar results were obtained after the use of organic copper forms. Statistically, a significant increase in this microelement concentration in egg content, shell, blood, and feathers was noticed and may confirm better absorption of copper from organic forms than copper sulphate (Dobrzański et al., 2008). However, the addition of organic forms of iron and manganese to the feed did not change the content of these mineral elements in the examined tissues; only in the group receiving the organic form of $\mathrm{Mn}$ was it significantly bigger in its feather content than in the control group. There was no interaction of copper, manganese, and iron with respect to zinc. Jegede et al. (2015) indicated the possibility of copper accumulation in egg yolk from the time of administration. 
Table 3. The content of mineral elements in each egg element depending on the group.

\begin{tabular}{llll|lll|llll}
\hline \multirow{2}{*}{ Trait } & \multicolumn{3}{c|}{ Yolk } & \multicolumn{3}{c|}{ Albumen } & \multicolumn{3}{c}{ Shell } \\
\cline { 2 - 10 } & NC & CHL & SEM & NC & CHL & SEM & NC & CHL & SEM \\
\hline $\mathrm{Cu}\left(\mathrm{mg} \mathrm{kg}^{-1}\right)$ & 3.44 & 3.52 & 0.177 & $1.58^{*}$ & $1.88^{*}$ & 0.081 & 2.45 & 2.03 & 0.279 \\
$\mathrm{Zn}\left(\mathrm{mg} \mathrm{kg}^{-1}\right)$ & 51.04 & 52.28 & 1.046 & $7.10^{*}$ & $9.18^{*}$ & 0.632 & 53.80 & 60.80 & 3.620 \\
$\mathrm{Fe}\left(\mathrm{mg} \mathrm{kg}^{-1}\right)$ & $88.80^{*}$ & $51.56^{*}$ & 2.589 & $17.68^{*}$ & $15.15^{*}$ & 0.831 & 61.00 & 55.80 & 5.780 \\
$\mathrm{Mg}\left(\mathrm{mg} \mathrm{kg}^{-1}\right)$ & $178.7^{*}$ & $153.3^{*}$ & 7.577 & $130.4^{*}$ & $248.6^{*}$ & 12.352 & 3.04 & 3.38 & 0.209 \\
$\mathrm{Ca}\left(\mathrm{mg} \mathrm{kg}^{-1}\right)$ & $1.23^{*}$ & $0.46^{*}$ & 0.030 & $11.9^{*}$ & $18.8^{*}$ & 1.620 & 38.38 & 38.20 & 0.342 \\
$\mathrm{P}\left(\mathrm{mg} \mathrm{kg}^{-1}\right)$ & & & & & & & 1.24 & 1.24 & 0.132 \\
\hline
\end{tabular}

$\mathrm{NC}$ - negative control group

$\mathrm{CHL}$ - group supplemented with copper chelate with lysine $30 \mathrm{mg} \mathrm{Cu} \mathrm{L}^{-1}$ in drinking water * Mean values differ at $p \leq 0.05$

However, the action of $\mathrm{Cu}$ depends on its form. There was significantly better efficiency in the organic (protein) form than the inorganic compound (copper sulphate), especially in terms of lowering cholesterol in blood serum and egg yolk. It seems that organic forms of trace mineral supplements may appear to be effective, but the complete replacement of inorganic trace mineral sources with organic mineral sources in the hen's diet allows a reduction in excreted trace minerals and does not negatively affect egg production or the quality of egg shells (Carvalho et al., 2015).

\section{Conclusions}

The supplementation of $30 \mathrm{mg} \mathrm{L}^{-1}$ of copper as its chelate with lysine improved the weight of the obtained eggs as well as the weight and height of the albumen. There were no changes in the shell strength parameters. Its darker color may increase the acceptance of the eggs by potential consumers, but this requires confirmation by sensory analysis of the raw material. There were minor changes in the mineral composition of each egg element.

The applied dose of copper resulted in changes of egg quality. It seems that the continuation of research is justified to determine the minimal effective dose of this micronutrient, as well as to establish the time of administration, to achieve the best quality of eggs, and to minimize mineral disorder in the organism.

Data availability. The original data are available upon request from the corresponding author.

Competing interests. The authors declare that they have no conflict of interest.

Edited by: Manfred Mielenz

Reviewed by: Teodora Popova and one anonymous referee

\section{References}

Ahmed, A. M. H., Rodriguez-Navarro, A. B., Vidal, M. L., Gautron, J., García-Ruiz, J. M., and Nys, Y.: Changes in eggshell mechanical properties, crystallographic texture and in matrix proteins induced by moult in hens, Brit. Poultry Sci., 46, 395-403, https://doi.org/10.1080/00071660120103675, 2005.

Ankari, A., Najib, H., and Hozab, A.: Yolk and serum cholesterol and production traits, as affected by incorporating a supraoptimal amount of copper in the diet of the leghorn hen, Brit. Poultry Sci., 39, 393-397, https://doi.org/10.1080/00071669888944, 1998.

Atia, F. A., Waibel, P. E., Hermes, I., Carlson, C. W., and Walseri, M. M.: Effect of dietary phosphorus, calcium, and phytase on performance of growing turkeys, Poultry Sci., 79, 231-239, 2000.

Batkowska, J. and Brodacki, A.: Selected quality traits of eggs and the productivity of newly created laying hen hybrids dedicated to an extensive rearing system, Arch. Anim. Breed., 60, 87-93, https://doi.org/10.5194/aab-60-87-2017, 2017.

Batkowska, J., Brodacki, A., and Knaga, S.: Quality of laying hen eggs during storage depending on egg weight and type of cage system (conventional vs. furnished cages), Ann. Anim. Sci., 14, 707-719, https://doi.org/10.2478/aoas-2014-0021, 2014.

Baumgartner, S., Brown, D., Salvysky Jr., E., and Leach Jr., R.: Copper deficiency in the laying hen, J. Nutr., 108, 804-811, 1978

Carvalho, L. S. S., Rosa, D. R. V., Litz, F. H., Fagundes, N. S., and Fernandes, E. A.: Effect of the inclusion of organic copper, manganese, and zinc in the diet of layers on mineral excretion, egg production, and eggshell quality, Braz. J. Poult. Sci., 17, 87-92, https://doi.org/10.1590/1516-635XSPECIALISSUENutritionPoultryFeedingAdditives087-092, 2015.

Council Directive 1999/74/EC of 19 July 1999 laying down minimum standards for the protection of laying hens, Official Journal of the European Communities, 3.8.1999 L 203/53, 1999.

Dobrzański, Z., Korczyński, M., Chojnacka, K., Górecki, H., and Opaliński, S.: Influence of organic forms of copper, manganese and iron on bioaccumulation of these metals and zinc in laying hens, J. Elementol., 13, 309-319, 2008.

Đukić-Stojčić, M., Perić, L., Bjedov, S., and Milošević, N.: The quality of table eggs produced in different housing systems, Biotechnol. Anim. Husb., 25, 1103-1108, 2009.

Esenbuğa, N., Macit, M., Karaoglu, M., Aksu, M. I., and Bilgin, O. C.: Effects of dietary humate supplementation to broilers on per- 
formance, slaughter, carcass and meat colour, J. Sci. Food Agr., 88, 1201-1207, https://doi.org/10.1002/jsfa.3199, 2008.

Fiske, C. H. and Subbarow, Y.: The colorimetric determination of phosphorus, J. Biol. Chem., 66, 375-400, 1925.

Fletcher, D. L., Britton, W. M., Pesti, G. M., Rahn, A. P., and Savage, S. I.: The relationship of layer flock age and egg weight on egg component yields and solids content, Poultry Sci., 62, 18001805, https://doi.org/10.3382/ps.0621800, 1983.

Franco, J. R. G. and Sakamoto, M. I.: Qualidade de ovos: uma visão geral dos fatores que a influenciam, Ave World, 3, 20-24, 2005.

Hunton, P.: Research on eggshell structure and quality: An historical overview, Braz. J. Poult. Sci., 7, 67-71, https://doi.org/10.1590/S1516-635X2005000200001, 2005.

IBM Corp.: Released, IBM SPSS Statistics for Windows, Version 20.0. Armonk, NY: IBM Corp., 2011.

Jegede, A. V., Oso, A. O., Fafiolu, A. O., Sobayo, R. A., Idowu, O. M. O., and Oduguwa, O. O.: Effect of dietary copper on performance, serum and egg yolk cholesterol and copper residues in yolk of laying chickens, Slovak J. Anim. Sci., 48, 29-36, 2015.

Lim, H. S. and Paik, I. K.: Effects of supplementary mineral methionine chelates $(\mathrm{Zn}, \mathrm{Cu}, \mathrm{Mn})$ on the performance and eggshell quality of laying hens, Asian. Austral. J. Anim., 16, 1804-1808, https://doi.org/10.5713/ajas.2003.1804, 2003.

Lim, K. S., You, S. J., An, B. K., and Kang, C. W.: Effects of dietary garlic powder and copper on cholesterol content and quality characteristics of chicken eggs, Asian. Austral. J. Anim., 19, 582-586, https://doi.org/10.5713/ajas.2006.582, 2006.

Lundeen, T.: Mineral proteinates may have positive effect on shell quality, Feedstuffs, 73, 10-15, 2001.

Menezes, P. C. D., Lima, E. R. D., Medeiros, J. P. D., Oliveira, W. N. K. D., and Evêncio-Neto, J.: Egg quality of laying hens in different conditions of storage, age and housing densities, Rev Bras Zootecn., 41, 2064-2069, https://doi.org/10.1590/S151635982012000900014, 2012.

Nestor, K. E. and Jaap, R. G.: Egg weight may influence albumen height, Poultry Sci., 42, 1249-1250, https://doi.org/10.3382/ps.0421249, 1963.

Olgun, O., Yazgan, O., and Cufadar, Y.: Effects of boron and copper dietary supplementation in laying hens on egg shell quality, plasma and tibia mineral concentrations and bone biomechanical properties, Rev. Med. Vet.-Toulouse, 163, 335-342, https://doi.org/10.5958/0976-0555.2014.00032.6, 2012.

Paik, I. K.: Nutritional management for environment friendly animal production, Asian. Austral. J. Anim., 13, 302-314, 2000.

Pekel, A. Y. and Aip, M.: Effects of different dietary copper sources on laying hen performance and egg yolk cholesterol, J. Appl. Poultry. Res., 20, 506-513, https://doi.org/10.3382/japr.201000313, 2011.
Safaa, H. M., Serrano, M. P., Valencia, D. G., Arbe, X., JiménezMoreno, E., Lázaro, R., and Mateos, G. G.: Effects of the levels of methionine, linoleic acid, and added fat in the diet on productive performance and egg quality of brown laying hens in the late phase of production, Poultry Sci., 87, 1595-1602, https://doi.org/10.3382/ps.2008-00005, 2008.

Sarica, M., Onder, H., and Yamak, U. S.: Determining the most effective variables for egg quality traits of five different hen genotypes, Int. J. Agr. Biol. Eng., 14, 235-240, 2012.

Sechinato, A. S., Albuquerque, R., and Nakada, S.: Efeito da suplementação dietética com micro minerais orgânicos na produção de galinhas poedeiras, Braz. J. Vet. Res. Anim. Sci., 43, 159166, 2006.

Skřivan, M., Skřivanová, V., and Marounek, M.: Effects of dietary zinc, iron, and copper in layer feed on distribution of these elements in eggs, liver, excreta, soil, and herbage, Poultry Sci., 84 , 1570-1575, https://doi.org/10.1093/ps/84.10.1570, 2005.

Stanćev, V., Puvača, N., Mili, D., Stanćev, V., and Drinić, M.: Microelements and their chelate forms in nutrition of monogastric animals: a review, Scientific Papers, Series D, Animal Science, 54, 90-96, 2013.

Wieleba, E. and Pasternak, K.: Pierwiastki śladowe w systemie antyoksydacyjnym zwierząt, Med. Weter., 57, 788-791, 2001 (in Polish)

Yenice, E., Mizrak, C., Gultekin, M., Atik, Z., and Tunca, M.: Effects of dietary organic or inorganic manganese, zinc, copper and chrome supplementation on the performance, egg quality and hatching characteristics of laying breeder hens, Ankara Univ. Vet. Fak., 62, 63-68, 2015.

Zhao, J., Shirley, R. B., Vazquez-Anon, M., Dibner, J. J., Richards, J. D., Fisher, P., Hampton T., Christensen K. D., Allard, J. P., and Giesen, A. F.: Effects of chelated trace minerals on growth performance, breast meat yield, and footpad health in commercial meat broilers, J. Appl. Poultry Res., 19, 365-372, https://doi.org/10.3382/japr.2009-00020, 2010.

Zita, L., Tůmová, E., and Štolc, L.: Effects of genotype, age and their interaction on egg quality in brown-egg laying hens, Acta Vet. Brno, 78, 85-91, https://doi.org/10.2754/avb200978010085, 2009. 